\title{
An Oral Live Attenuated Vaccine Strategy against Severe Acute Respiratory Syndrome Coronavirus 2 (2019-nCoV)
}

\section{Sanal Madhusudana Girija ${ }^{1}$, Ravi Chandra Dubey ${ }^{2}$}

\author{
${ }^{1}$ Institute of Liver \& Biliary Sciences, D1-Vasant Kunj, New Delhi 110070 \\ ${ }^{2}$ South Asian University, Akbar Bhawan, Satya Marg, Chanakyapuri, New Delhi, Delhi 110021 \\ Corresponding author: Sanal Madhusudana Girija, Department of Cellular \& Molecular Medicine, \\ Institute of Liver \& Biliary Sciences, D1-Vasant Kunj, New Delhi 110070 \\ email: sanalmg@gmail.com, smgirija@ilbs.in
}

\begin{abstract}
Severe acute respiratory syndrome coronavirus 2 (SARS-Cov-2/2019-nCoV) infection is an emerging pandemic. The virus binds to angiotensin converting enzyme 2 (ACE2) and TMPRSS2 which are abundantly expressed on various human cells including lung epithelial cells and intestinal cells and the virus can infect these cells. Currently no specific treatments or vaccines are available for this disease. A per oral live attenuated vaccine can be beneficial in SARS-Cov-2 infection because the attenuated virus initially infects the gut, stimulates the mucosa associated immune system sparing the respiratory system during the initial immune response. The live virus can also spread in the community boosting herd immunity.
\end{abstract}

Severe acute respiratory syndrome coronavirus 2 infection has become a pandemic called Coronavirus disease 2019 (COVID-19). Protein modeling experiments on the spike protein of the virus suggested that SARS-CoV-2 has sufficient affinity to the angiotensin converting enzyme 2 (ACE2) and TMPRSS2 receptors on human cells to use them as a mechanism of cell entry. Later it was experimentally demonstrated that ACE2 could act as the receptor for SARS-CoV-2 (1). Diarrhea is one of the early symptoms in a significant population of COVID-19 patients (2). The expression profiles of ACE2 in various human tissues found that ACE2 was highly expressed in the human small intestine (proximal and distal enterocytes) while the RNA level of ACE2 was quite low in lung tissues from healthy donors (3). Immune response against 2019-nCov is believed to be effective in man. So far, no significant cases of re-infection are reported. A recent study on monkeys also confirms this view (4). We propose a live attenuated 2019-nCov vaccine which would be administered orally so that it will initially infect intestinal cells, temporarily colonize gut and generate 
immunity. The danger of infecting lungs directly and immediate the risk of lung infection and inflammation can be avoided. An attenuated vaccine is a vaccine made by mutating the virulence of a pathogen through various methods, for example through multiple passages in cell culture, but keeping it live. The virus becomes harmless or less virulent but capable to generate an immune response. A live attenuated influenza vaccine is used for influenza vaccine in the form of a nasal spray. However, for 2019-nCoV an oral route could be better considering the abundance of ACE2 in gastrointestinal track. Besides the mucosa-associated lymphoid tissue (MALT), a diffuse system of lymphoid tissue found in various submucosal membrane sites of the body, such as the gastrointestinal tract, would help in achieving a strong immune response against the virus. Compared to intramuscular injections, peroral administration is easy and cost effective.

\section{Severe acute respiratory syndrome coronavirus 2}

Severe acute respiratory syndrome coronavirus 2 (SARS-CoV-2) or the 2019 novel coronavirus (2019$\mathrm{nCoV}$ ), is a positive-sense single-stranded RNA virus (5). SARS-CoV-2 has been sequenced and the phylogenetic analysis suggested that the virus might have originated from bat origin (6). It causes a disease known as coronavirus disease 2019 (COVID-19) which has predominantly respiratory symptoms. SARSCoV-2 spreads among humans (RO of 2-2.5) and the World Health Organization (WHO) has declared the ongoing pandemic of COVID-19 an International Public Health Emergency. The SARS-CoV-2 was first discovered in Wuhan, China. The disease (COVID-19) spread rapidly and killed about 54,000 people as on 3 April 2020. A few vaccine trials are ongoing (table-1), however, no vaccines are currently available for COVID-19. To our knowledge none of the clinical trials are using an oral live attenuated vaccine strategy. No specific therapeutics are currently available, and current management is limited to travel restrictions, patient isolation, and supportive medical care. However, recently there are some studies reporting the effectiveness of hydroxychloroquine and Remdesivir (7).

\section{Intestinal Cells are rich in ACE2 which is a 2019-nCoV Receptor}

The virus enters human cells by binding to angiotensin converting enzyme 2 (ACE2) receptors. This was predicted using computer modeling. SARS-CoV spike protein has a strong binding affinity to human ACE2, based on biochemical interaction studies and crystal structure analysis. The glutamine amino acid residue at position 394 in the SARS-CoV-2 receptor-binding domain corresponding to residue 479 in SARS-CoV, will interact with the critical lysine at position 31 on the human ACE2 receptor (4,8). Diarrhea is an important symptom COVID-19. ACE2 is richly expressed in proximal and distal enterocytes and the virus infects gut epithelial cells (2).

\section{Oral Live attenuated Vaccine for 2019-nCoV}

A vaccine is expected to be effective for COVID-19 because the virus, Corona Virus, is a large and complex virus compared to other RNA virus, possesses several essential and conserved domains and a recent study reported that reinfection could not occur in SARS-CoV-2 infected rhesus macaques (4). Live vaccines contain weakened/attenuated form of the pathogenic organism (2019-nCoV) that causes a disease (COVID-19). Since the pathogens used in live vaccines causes an infection similar to natural infection, a 
strong and lasting immune response develops against the pathogen but without causing the actual disease.

We could infect and serially passage 2019-nCoV in Vero cells [ATCC-1586] (10), (a cell line from African Green Monkey (Chlorocebus sp.) which used for the production of several attenuated and inactivated viral vaccines), expressing ACE2-the COVID-19 receptor. Vero cells unlike other cell lines, does not secrete interferon $\alpha / \beta$ when infected by a virus (9). 2019-nCoV can infect Vero cells expressing ACE2. Accumulation of genomic mutation with serial passaging at suboptimal temperatures would make the virus weaken and less pathogenic. The serially passaged virus would eventually be allowed to infect human intestinal cell line such as Hs 1.Int /HuTu 80/ Caco-2 after experimentally verifying the expression of ACE2, infectivity and viral replication (10). Alternatively, a genetic reassortment between attenuated donor Corona Virus strain and 2019-nCoV can be achieved (11). This strategy has the potential to provide an extended coverage to heterologous infections which is possibility with RNA viruses along the course of the epidemic due to inherent mutability and generation of hybrid viruses by genetic mixing with other wild viruses $(11,15)$.

The live attenuated virus would be perorally administered. The virus would infect the intestinal cells, multiply and expected to provide a long-lasting immunity. The advantages of these live vaccines are "community spread" and faster development of herd immunity and the ease of administration. The live vaccine is potentially transmissible, speeding the herd immunity in the community (12). Live vaccine contains the live virus although attenuated. Theoretically, it is possible that through mutations the virus can revert to is wild strain. Therefore, some live vaccines are administered only in healthy people ages 5 to 49 . It may be noted that $70-90 \%$ of the healthy people recovers from COVID-19 without the need for hospitalization and most of the mortality occurs in old, diabetic and immunocompromised patients who would not be eligible for a live vaccine. However, it may be noted that, if $40-60 \%$ of the population becomes infected with 2019-CoV, herd immunity develops sufficiently to break and block the transmission chain which is a major advantage of this live vaccine strategy (13).

\begin{tabular}{|c|c|c|c|c|}
\hline \multirow[t]{2}{*}{ Table-1 } & \multicolumn{4}{|c|}{ Ongoing Covid-19 Vaccine Trials } \\
\hline & Study title & Method/Aim & Location & \\
\hline 1 & $\begin{array}{l}\text { Safety and Immunity } \\
\text { of Covid-19 aAPC } \\
\text { Vaccine }\end{array}$ & $\begin{array}{l}\text { Covid-19 minigenes engineered } \\
\text { based on multiple viral genes, } \\
\text { using an efficient lentiviral } \\
\text { vector system (NHP/TYF) to } \\
\text { express viral proteins and } \\
\text { immune modulatory genes to } \\
\text { modify artificial antigen } \\
\text { presenting cells (aAPC) and to } \\
\text { activate T cells. In this study, the } \\
\text { safety and immune reactivity of } \\
\text { this aAPC vaccine will be } \\
\text { investigated. }\end{array}$ & $\begin{array}{l}\text { Shenzhen } \\
\text { Immune } \\
\text { Institute }\end{array}$ & $\begin{array}{c}\text { Geno- } \\
\text { Medical }\end{array}$ \\
\hline 2 & $\begin{array}{l}\text { Immunity and Safety of } \\
\text { Covid-19 Synthetic } \\
\text { Minigene Vaccine }\end{array}$ & $\begin{array}{l}\text { Covid-19 minigenes engineered } \\
\text { based on multiple viral genes, } \\
\text { using an efficient lentiviral }\end{array}$ & $\begin{array}{l}\text { Shenzhen } \\
\text { Immune } \\
\text { Institute }\end{array}$ & $\begin{array}{r}\text { Geno- } \\
\text { Medical }\end{array}$ \\
\hline
\end{tabular}




\begin{tabular}{|c|c|c|c|}
\hline & & $\begin{array}{l}\text { vector system (NHP/TYF) to } \\
\text { express viral proteins and } \\
\text { immune modulatory genes to } \\
\text { modify dendritic cells (DCs) and } \\
\text { to activate T cells. }\end{array}$ & \\
\hline 3 & $\begin{array}{l}\text { Reducing Health Care } \\
\text { Workers Absenteeism } \\
\text { in Covid-19 Pandemic } \\
\text { Through BCG Vaccine }\end{array}$ & $\begin{array}{l}\text { The risks of BCG vaccination are } \\
\text { considered low. The objective of } \\
\text { this trial is to evaluate the } \\
\text { beneficial effects of BCG } \\
\text { vaccination through a lower } \\
\text { work absenteeism rate of HCW } \\
\text { and/or a mitigated clinical } \\
\text { course of Covid-19 infection. }\end{array}$ & $\begin{array}{l}\text { UMC Utrecht, } \\
\text { Radboud University }\end{array}$ \\
\hline 4 & $\begin{array}{l}\text { Safety and } \\
\text { Immunogenicity Study } \\
\text { of 2019-nCoV Vaccine } \\
\text { (mRNA-1273) for } \\
\text { Prophylaxis SARS CoV- } \\
2 \text { Infection }\end{array}$ & $\begin{array}{l}\text { mRNA-1273 is a novel lipid } \\
\text { nanoparticle } \\
\text { (LNP)- } \\
\text { encapsulated mRNA-based } \\
\text { vaccine that encodes for a full- } \\
\text { length, prefusion stabilized } \\
\text { spike (S) protein of SARS-CoV-2. }\end{array}$ & $\begin{array}{l}\text { Emory Vaccine } \\
\text { Center - The Hope } \\
\text { Clinic } \\
\text { Decatur, Georgia, } \\
\text { US National } \\
\text { Institutes of Health, } \\
\text { Kaiser Permanente }\end{array}$ \\
\hline 5 & $\begin{array}{l}\text { BCG Vaccination to } \\
\text { Protect Healthcare } \\
\text { Workers Against } \\
\text { COVID-19 }\end{array}$ & $\begin{array}{l}\text { Subjects will be randomized to } \\
\text { receive a single dose of BCG } \\
\text { vaccine, or no BCG vaccine. } \\
\text { Participants will be followed-up } \\
\text { for } 12 \text { months to identify } \\
\text { COVID-19 infection. }\end{array}$ & $\begin{array}{l}\text { Royal Children's } \\
\text { Hospital } \\
\text { Melbourne, } \\
\text { Victoria, Australia }\end{array}$ \\
\hline 6 & $\begin{array}{l}\text { A Phase I Clinical Trial } \\
\text { in } 18-60 \text { Adults }\end{array}$ & $\begin{array}{l}\text { To understand the safety, } \\
\text { reactogenicity and } \\
\text { immunogenicity of } \\
\text { Recombinant Novel } \\
\text { Coronavirus Vaccine } \\
\text { (Adenovirus Type } 5 \text { Vector). } \\
\text { Intramuscular (IM) injection of } \\
\text { experimental vaccine }\end{array}$ & $\begin{array}{l}\text { Hubei Provincial } \\
\text { Center for Disease } \\
\text { Control } \\
\text { Prevention } \\
\text { Wuhan, } \\
\text { China }\end{array}$ \\
\hline 7. & $\begin{array}{l}\text { A Study of a Candidate } \\
\text { COVID-19 Vaccine } \\
\text { (COV001) }\end{array}$ & $\begin{array}{l}\text { A phase I/II single-blinded, } \\
\text { randomised, placebo } \\
\text { controlled, multi-centre study } \\
\text { to determine efficacy, safety } \\
\text { and immunogenicity of the } \\
\text { candidate Coronavirus Disease } \\
\text { (COVID-19) vaccine ChAdOx1 } \\
\text { nCoV-19 in UK healthy adult } \\
\text { volunteers aged 18-55 years. } \\
\text { The vaccine will be } \\
\text { administered intramuscularly } \\
\text { (IM). }\end{array}$ & $\begin{array}{l}\text { NIHR WTCRF, } \\
\text { University Hospital } \\
\text { Southampton NHS } \\
\text { Foundation Trust } \\
\text { Imperial College } \\
\text { University of Oxford }\end{array}$ \\
\hline
\end{tabular}


Reference\#14:

https://clinicaltrials.gov/ct2/results?cond=Covid+vaccine\&term=\&cntry=\&state=\&city=\&dist=

Accessed on 5 April 2020, 20:20 IST

\section{References}

1) Angiotensin-converting enzyme 2 (ACE2) as a SARS-CoV-2 receptor: molecular mechanisms and potential therapeutic target Haibo Zhang, Josef M. Penninger, Yimin Li, Nanshan Zhong \& Arthur S. Slutsky Intensive Care Medicine volume 46, pages586-590(2020)).

2) Liang, Weicheng, et al. "Diarrhoea may be underestimated: a missing link in 2019 novel coronavirus." Gut (2020).

3) Reinfection could not occur in SARS-CoV-2 infected rhesus macaques. Bao L, Deng W, Gao H et al. https://doi.org/10.1101/2020.03.13.990226.

4) Zhang, Haibo, et al. "Angiotensin-converting enzyme 2 (ACE2) as a SARS-CoV-2 receptor: molecular mechanisms and potential therapeutic target." Intensive Care Medicine (2020): 1-5.

5) Surveillance case definitions for human infection with novel coronavirus ( $\mathrm{nCoV}$ ): interim guidance v1, January 2020 (Report). World Health Organization. January 2020. hdl:10665/330376

6) Wan, Yushun, et al. "Receptor recognition by the novel coronavirus from Wuhan: an analysis based on decade-long structural studies of SARS coronavirus." Journal of virology 94.7 (2020).

7) Wan, Yushun, et al. "Receptor recognition by the novel coronavirus from Wuhan: an analysis based on decade-long structural studies of SARS coronavirus." Journal of virology 94.7 (2020).

8) Li, Fang, et al. "Structure of SARS coronavirus spike receptor-binding domain complexed with receptor." Science 309.5742 (2005): 1864-1868.

9) Ammerman, Nicole C., Magda Beier-Sexton, and Abdu F. Azad. "Growth and maintenance of Vero cell lines." Current protocols in microbiology 11.1 (2008): A-4E.

10) https://www.atcc.org

11) Jang, Yo Han, and Baik-Lin Seong. "Principles underlying rational design of live attenuated influenza vaccines." Clinical and experimental vaccine research 1.1 (2012): 35-49.

12) Bull, James J., Mark W. Smithson, and Scott L. Nuismer. "Transmissible viral vaccines." Trends in microbiology 26.1 (2018): 6-15.

13) Horton, Richard. "Offline: COVID-19-a reckoning." The Lancet 395.10228 (2020): 935.

14) https://clinicaltrials.gov/ct2/results?cond=Covid+vaccine\&term=\&cntry=\&state=\&city=\&dist=

15) Andersen, Kristian G., et al. "The proximal origin of SARS-CoV-2." Nature Medicine (2020): 1-3. 